\title{
TOURISM ECONOMY OF KEMEROVO REGION IN 2009-2017: STRATEGIES, RESULTS, AND CHALLENGES
}

\author{
Sergey A. Vasyutin, Elena N. Deniskevich, \\ Oleg V.Kim, Roman V. Selezenev and \\ Konstantin V.Yumatov \\ Department of World History and Socio-Political Sciences \\ Kemerovo State University \\ Kemerovo, Russia
}

\author{
Nataliya S. Yakimova \\ Department of Foreign Languages \\ in Professional Communication \& \\ Department of Economic Theory and Public Administration \\ Kemerovo State University \\ Kemerovo, Russia \\ nataliyayakimova@mail.ru
}

\begin{abstract}
The article presents a comprehensive analysis of the development of tourism industry in Kemerovo region in 2009 . 2017. The study is based on the analysis of a number of socioeconomic statistical indicators: the amount of tourist services rendered to the population, investments in fixed assets, the growth of the number of hotel rooms, the dynamics of the number of accommodation facilities' employees. The competitiveness of Kuzbass in comparison with other Siberian regions is analyzed. The regional authorities' policy, including the regional legislation in the field of tourism and the 2025 Strategy for Tourism Development in Kuzbass, is studied. Examples of successful development of Kuzbass tourist destinations are shown. The analysis shows that concerning the amount of tourist services provided to the population, Kemerovo region ranks first in the Siberian Federal district, and since 2012, stably ranks among the 12 best regions in Russia. This is supported by a purposeful policy of the regional authorities aimed at tourism development, including the implementation of public-private partnerships and the creation of cluster associations. It is concluded that the tourism industry is of strategic importance for Kemerovo region's economy in the context of attracting investments, increasing jobs, incomes, taxes, and other micro- and macroeconomic indicators.
\end{abstract}

Keywords - tourism, Kemerovo Region, investments, tourism infrastructure

\section{INTRODUCTION}

Tourism, as a branch of post-industrial economy, allows solving a wide range of important socio-economic problems. These include solving the problems of expanded reproduction of labour resources, increasing employment, increasing welfare and improving the quality of life of the society, and ensuring the socio-cultural development of the population.

Kemerovo region (also known as Kuzbass - after Kuznetsk Coal Basin, where a great part of the region's territory is located) is one of the leaders for tourism development in the Siberian Federal district [1]. Federal and regional programs aimed at stimulating the development of infrastructure, wider use of natural and urban recreation facilities, and the emergence of new attractions in the already operating tourist complexes have been of great importance for tourism development in Kuzbass. The contribution of a private business companies (especially in the development of the Sheregesh, Tanay, Gornaya Salanga ski resorts, etc.) is hard to overestimate. Many economic indicators of tourism industry development in Kuzbass in 2009-2017 showed positive trends, despite the global economic crisis of 20082011, the introduction of economic sanctions and restrictions in 2014 , and the competition with neighbouring regions. At the same time, it should be stated that Kemerovo region residents' involvement in the sphere of recreation and entertainment and the amount of tourist services are insufficient, and further investments both in large projects (transportation, creating new accommodation facilities and complex entertainment zones) and in the proposals of small businesses are required.

It was in 2009 that a number of Kemerovo region laws regulating the tourism sector were approved and the region's "Strategy for social and economic development through 2025" was launched, where tourism was assigned a very important role. The availability of important statistical data on the development of tourism in the Russian regions, which have been collected by RussiaTourism since 2009, explain the chronological framework of this study. Some earlier data for 2004-2009 had been analyzed by Tolstykh and Litvak [2].

\section{PRoblem Statement AND ReSEARCH Questions}

The main problems in studying the development of tourism in Russia are related to identifying the criteria and indicators that allow for objective assessment of the tourism economy development. It is argued that in Russia, over 50 statistical forms represent the main tourism indicators [3]. Thus, researchers have suggested different criteria for evaluating the development of tourism in a region, e.g. the number of tourism arrivals, the origin of the tourists; the number of collective accommodation facilities, rooms and people accommodated; the number of catering companies; the number of tourism companies [4]; the number of tour 
operators, and the amount of tourism, hotel and resort services [5]; the travel and tourism contribution to the GDP and to employment [3]; the number of domestic and international arrivals, tourism share in the regional GDP, and the number of travel agents and commercial accommodation facilities [1]. In this article 7 statistical criteria were selected for analyzing the development of tourism in Kemerovo region in 2009-2017, namely: the amount of paid tourist services provided, the amount of paid services provided by accommodation facilities, the number of accommodation facilities, the number of 3- or more- star hotels, the number of accommodation facilities' employees, the number of Russian citizens who stayed at accommodation facilities, and the amount of taxes paid by industry representatives to all budgets.

It is also necessary to determine the role of the national and regional policy in the strategy of the industry development, to assess the amount of investment in the tourism industry over the studied period and to analyze the qualitative development of tourism infrastructure. The Russian national legislative acts regulating tourist activity were introduced as early as in the mid-1990s, while the first Kemerovo Region law "On tourist activity" was only adopted in 2009 [6]. Effective development of tourism industry both at the national and at the regional level demanded for the introduction of specific legal acts regulation the collaboration of tourism industry stakeholders: regional authorities, private business, knowledge institutions and museums [7], and this article will discuss their effect of the development of tourism in Kuzbass.

Thus, the article will focus on two research questions. Firstly, the growth of the tourism industry in Kemerovo region in 2009-2017 will be assessed through analyzing such indicators as the amount of tourist services provided, the development of domestic tourism in the region, the growth in the number and size of rooms at accommodation facilities, the dynamics of the number of accommodation facilities' employees, and the competitiveness of Kuzbass compared with other Siberian regions in these aspects of the tourism sector development. Secondly, the authors will discuss the effectiveness of tourism development programs implemented in the period under review.

\section{Purpose of THE Study AND Methodology}

The aim of the study is to provide a comprehensive assessment of the development of tourism in Kemerovo region in 2009-2017 and raking it against other regions of the Siberian Federal District and other Russian regions, and to assess the regional legal acts supporting this development.

The authors studied and analyzed the statistical data of the Federal Agency for Tourism (RussiaTourism) on the development of the main components of Kuzbass tourism industry. The analysis of legal acts was performed. The comparative method was used to assess the degree of tourism economy development in the regions of Siberian Federal District and Russia. Functional analysis of the activities of regional authorities for developing tourism in Kuzbass was carried out.

\section{RESULTS AND DISCUSSION}

Statistical data of the Federal Tourism Agency show that Kemerovo region has taken a major step in the development of the tourist services market. While in 2009 the amount of tourist services provided to the population was 729.7 million [8], in following years there was a significant increase in this indicator, especially in 2010 (3.049 billion rubles) and in 2013 (4.191 billion rubles). In the next two years (2014-2015), the sharp drop in the purchasing power of the ruble had a positive impact on domestic tourism development, as it made travel and recreation in Russia more affordable for foreign tourists, and made foreign travel less affordable for Russian tourists [9]. It is no coincidence that the ski resort (sports and tourist complex) Sheregesh has witnessed a record-breaking number of arrivals in those years: more than 940 thousand tourists in 2014, and more than a million tourists in 2015 [10]. It should be noted that in Kuzbass there are a lot of attractive natural, recreational, historical and cultural tourist resources, various sports and entertainment centres, but the economic indicators of Sheregesh are of fundamental importance for the tourist industry of Kemerovo region. In general, in 2014-2015, the income from providing tourist services remained fairly high: 4.376 billion rubles in 2014 and 4.256 billion rubles in 2015 . In 2016, there was quite a sharp drop in the income from industry to 3.884 billion rubles. It was due to the prolonged stagnation of the economy, which had lasted for several years, the decline in real income of the population of Russia, the competition from neighbouring regions, etc. Thus, it can be stated that the tourism industry is sensitive to any negative phenomena in the economy, and it develops unevenly. Nevertheless, regarding the amount of tourist services provided, Kemerovo region ranks first in the Siberian Federal district (Table I) and since 2012 it has been consistently ranking among the top twelve regions of Russia (Table II).

Statistics show that, while maintaining the leadership by the amount of tourist services rendered to population in the Siberian Federal District, Kuzbass was losing its position among the top-12 tourist Russian regions in 2014-2016. There were objective reasons for such changes. The capital of Russia - Moscow, St. Petersburg, Moscow region, Nizhny Novgorod, Sverdlovsk and Tyumen regions initially had the best economic results and financial resources. Moscow and St. Petersburg have enormous historical and cultural potential. Krasnodar Krai and the Republic of Crimea have received big amounts of investment, and they are areas with much more favourable conditions for recreation than the Kuzbass. The Republic of Bashkortostan, Perm Krai and Chelyabinsk region have been able to significantly increase the profitability of the tourism sector over 5 years. 
TABLE I. THE AMOUNT OF TOURISM SERVICES PROVIDED IN THE REGIONS OF SIBERIAN FEDERAL DISTRICT, MILLION RUBLES [8]

\begin{tabular}{|c|c|c|c|c|c|c|c|c|}
\hline \multirow{2}{*}{$\begin{array}{c}\text { Regions of } \\
\text { Siberian Federal District }\end{array}$} & \multicolumn{9}{|c|}{ Years } \\
\cline { 2 - 9 } & $\mathbf{2 0 0 9}$ & $\mathbf{2 0 1 0}$ & $\mathbf{2 0 1 1}$ & $\mathbf{2 0 1 2}$ & $\mathbf{2 0 1 3}$ & $\mathbf{2 0 1 4}$ & $\mathbf{2 0 1 5}$ & $\mathbf{2 0 1 6}$ \\
\hline Altai Republic & 75.4 & 69.7 & 117.1 & 113.4 & 114.9 & 116.1 & 138.6 & 153.0 \\
\hline Republic of Buryatia & 234.3 & 280.9 & 335.0 & 435.9 & 795.5 & 894.3 & 1010.1 & 1068.4 \\
\hline Tyva Republic & 4.4 & 4.9 & 6.3 & 19.1 & 20.0 & 20.4 & 21.9 & 24.1 \\
\hline Republic of Khakassia & 99.0 & 86.1 & 120.5 & 123.8 & 132.3 & 130.7 & 137.9 & 139.7 \\
\hline Altai Krai & 745.9 & 780.4 & 867.6 & 928.6 & 1014.5 & 859.4 & 931.2 & 952.6 \\
\hline Transbaikal Kray & 525.4 & 739.9 & 825.6 & 892.1 & 1147.0 & 982.2 & 702.6 & 737.4 \\
\hline Krasnoyarsk Kray & 1381.9 & 2790.5 & 3645.2 & 3842.5 & 2891.9 & 3049.2 & 2519.1 & 2499.7 \\
\hline Irkutsk Region & 1083.4 & 1017.7 & 1192.0 & 1429.8 & 1468.3 & 1550.8 & 1882.9 & 2031.6 \\
\hline Kemerovo Region & 759.9 & 2355.2 & 2700.7 & 3354.5 & 4372.0 & 4376.9 & 4256.5 & 3884.8 \\
\hline Novosibirsk Region & 729.7 & 3049.6 & 3238.3 & 3317.4 & 4191.7 & 3487.2 & 2872.2 & 3613.1 \\
\hline Omsk Region & 977.8 & 1150.2 & 1324.3 & 1464.8 & 1775.2 & 1884.7 & 1883.3 & 1589.1 \\
\hline Tomsk Region & 485.1 & 763.4 & 1139.0 & 1299.4 & 1455.1 & 1492.5 & 1640.4 & 1611.2 \\
\hline
\end{tabular}

TABLE II.

TOP 10 REGIONS OF RUSSIA REGARDING THE AMOUNT OF TOURISM SERVICES PROVIDED, MILLION RUBLES [8]

\begin{tabular}{|c|c|c|c|c|c|c|c|c|c|c|}
\hline \multirow{3}{*}{$\begin{array}{c}\begin{array}{c}\text { Regions of } \\
\text { Russia }\end{array} \\
\text { Moscow }\end{array}$} & \multicolumn{10}{|c|}{ Years / Rank } \\
\hline & \multicolumn{2}{|c|}{2012} & \multicolumn{2}{|c|}{2013} & \multicolumn{2}{|c|}{2014} & \multicolumn{2}{|c|}{2015} & \multicolumn{2}{|c|}{2016} \\
\hline & 20749.3 & 1 & 27444.6 & 1 & 22204.6 & 1 & 24542.2 & 1 & 22644. & 1 \\
\hline Moscow Region & 3047.0 & 9 & 6839.9 & 4 & 7004.0 & 5 & 7158.2 & 4 & 7287.0 & 4 \\
\hline Saint-Petersburg & 8307.6 & 3 & 9266.9 & 3 & 8804.1 & 3 & 6641.5 & 5 & 6679.8 & 7 \\
\hline $\begin{array}{c}\text { Republic of Crimea and Sevastopol } \\
\text { (Crimea Federal District) }\end{array}$ & - & - & - & - & 324.2 & 12 & 4717.8 & 8 & 6890.6 & 6 \\
\hline Krasnodar Krai & 3844.6 & 6 & 4354.7 & 7 & 5290.5 & 6 & 6509.6 & 6 & 7253.8 & 5 \\
\hline Sverdlovsk Region & 11227.9 & 2 & 12545.8 & 2 & 13616.4 & 2 & 15847.8 & 2 & 13606.1 & 2 \\
\hline Bashkortostan Republic & 2742.3 & 11 & 3366.8 & 11 & 3870.5 & 9 & 4157.6 & 10 & 4344.3 & 9 \\
\hline Perm Krai & 2834.6 & 10 & 3335.7 & 10 & 3027.3 & 11 & 2824.3 & 12 & 4051.6 & 10 \\
\hline Nizhny Novgorod Region & 3866.2 & 5 & 5634.0 & 5 & 7243.8 & 4 & 7173.5 & 3 & 7495.6 & 3 \\
\hline Chelyabinsk Region & 3985.8 & 4 & 4020.3 & 9 & 5226.0 & 7 & 4846.0 & 7 & 4653.5 & 8 \\
\hline Kemerovo Region & 3354.5 & 7 & 4372 & 6 & 4376.9 & 8 & 4256.5 & 9 & 3884.8 & 11 \\
\hline Novosibirsk Region & 3317.4 & 8 & 4191.7 & 8 & 3487.2 & 10 & 2872.2 & 11 & 3613.1 & 12 \\
\hline
\end{tabular}

RussiaTourism provides statistics on other important indicators of the tourism economy in the regions of Russia. According to the majority of indicators (the number of citizens of the Russian Federation who stayed at collective accommodation facilities in 2009-2016, the number of Russian and foreign citizens who stayed at collective accommodation facilities in 2016, the number of rooms at accommodation facilities in 2009-2016, investments in fixed assets aimed at the development of the accommodation facilities in 2009-2016) Kemerovo region ranked 4th among 12 regions of the Siberian Federal district. According to the average number of accommodation facilities' employees, Kuzbass ranked the second (6123 employees in 2016) in the
Siberian Federal District. Concerning the amount of services provided by accommodation facilities, as well as the number of people working in tourism companies, Kuzbass ranked third. Yet, regarding the number of beds in collective accommodation facilities Kemerovo region ranked fifth.

What strategic legislative and investment mechanisms have contributed to the dynamic development of Kemerovo region's tourism industry? Let us consider a number of regional and municipal acts aimed at creating favourable conditions for the development of the tourism sector and attracting financial resources to the tourism industry of Kuzbass. 
First, the Strategy for social and economic development through 2025 approved by the Law of 11.06.2008, № 74-OZ [11]. This strategy closely linked the comprehensive development of Kuzbass with the development of tourism. The authors of the strategy consider tourism as a significant indicator (marker) of socio-economic development of Kemerovo region in the long term. They focus on the support and implementation of new unique projects, including Sheregesh and Tanay ski resorts. At the time when the Strategy was prepared, the following figures were a reality for Sheregesh: eight lifts, 25 hotels with 700 beds, seven service facilities, 18 cafes, two restaurants and 100000 tourists a year. Yet, the Strategy determined the following target capacity of the resort: a hotel complex with up to 4960 beds, 21 lifts, 39 ski slopes $(140 \mathrm{~km})$, creation of more than 4000 new jobs, and hosting more than 300000 tourists a year. In 2017, there are more than 70 hotels (more than 3000 beds), 21 ski slopes, 19 lifts, and 62 cafes and restaurants in Sheregesh. More than 2500 jobs have been created and the milestone of 1000000 tourists a year has been reached, as mentioned above. Thus, despite the fact that the determined target capacity has not been reached yet (although the number of tourists has significantly exceeded it), the positive dynamics in the development of Sheregesh ski resort is obvious. quality rest [13]. The implementation of a comprehensive approach to the development of the industry is the target scenario (compared to the baseline scenario). It should be achieved through: a significant increase in funding; focusing on developing the region's most promising districts and municipalities from the point of view of developing domestic and inbound tourism; focusing on the key types of domestic and inbound tourism; effective implementation of investment projects of public-private partnership; attracting private capital for the successful and efficient development of local tourism infrastructure. The Strategy determined the development of regional economic zones with tax breaks as the mechanism for attracting large investors to the region and introducing advanced technologies.

The effectiveness of the target scenario implementation should be assessed at three stages (2013-2015, 2016-2020, 2021-2025) with a number of indicators that are used in strategic and policy documents adopted at the level of the Russian Federation (see Table III).

Comparing the determined indicators to the statistical data for 2014-2016 [8], we can see that the amount of paid tourist services rendered to the population in 2014 exceeded 4 billion rubles, which is above the target indicator determined for 2025, while the number of paid services provided by Kuzbass

TABLE III. EXPECTED RESULTS OF THE 2025 STRATEGY FOR TOURISM DEVELOPMENT IN KUZBASS [13]

\begin{tabular}{|c|c|c|c|c|c|c|c|}
\hline \multirow{2}{*}{ Indicators and measurements } & \multirow{2}{*}{$\begin{array}{c}\text { Initial data } \\
2011\end{array}$} & \multicolumn{3}{|c|}{ Target scenario } & \multicolumn{3}{|c|}{ Baseline scenario } \\
\hline & & 2015 & 2020 & 2025 & 2015 & 2020 & 2025 \\
\hline $\begin{array}{l}\text { Amount of paid tourist services provided, } \\
\text { billion rubles }\end{array}$ & 0.62 & 1.35 & 2.03 & 3.04 & 1.06 & 1.58 & 2.37 \\
\hline $\begin{array}{l}\text { Amount of paid services provided by } \\
\text { accommodation facilities, billion rubles }\end{array}$ & 0.74 & 1.23 & 1.78 & 2.32 & 0.98 & 1.25 & 1.55 \\
\hline Number of accommodation facilities, units & 146 & 176 & 206 & 246 & 156 & 176 & 196 \\
\hline $\begin{array}{l}\text { Number of accommodation facilities' } \\
\text { employees, thousand people }\end{array}$ & 5.8 & 7.3 & 8.2 & 9.8 & 6.2 & 7.3 & 8.1 \\
\hline $\begin{array}{l}\text { Number of Russian citizens who stayed at } \\
\text { accommodation facilities, thousand people }\end{array}$ & 263.8 & 318.5 & 370.8 & 446.8 & 280.8 & 318.5 & 352.8 \\
\hline $\begin{array}{l}\text { Taxes paid by industry representatives to } \\
\text { all budgets, million rubles }\end{array}$ & 997.3 & 1437.3 & 1837.3 & 2237.3 & 1118.5 & 1270.0 & 1421.5 \\
\hline
\end{tabular}

In 2009, a number of regional laws regulating the development of tourism in Kuzbass were adopted, namely: Kemerovo Region Law №5-OZ "On tourist activity" dated 06.02.2009, Kemerovo Region Law № 88-OZ "On the development of domestic and incoming tourism" dated 13.07.2009, and Kemerovo Region Law 67-OZ "On the development of snow tourism in Kemerovo" dated 08.06.2009 [12]. These normative legal acts established the goals and priorities of the state regulation of tourist activity in Kemerovo region, and defined the competencies of the regional authorities in regulating tourism. The "2025 Strategy for tourism development in Kuzbass" was adopted by the Decree of Kemerovo Region Administration Board № 194-p dated 1 March 2013. It established the goal of forming a modern competitive tourism and recreation complex in Kemerovo region providing a wide scope of opportunities for the growth of domestic and international tourist flows, and developing the tourist infrastructure to meet the population's need for high- accommodation facilities in 2016 was close to the target indicator determined for 2015. In 2015, the actual number of accommodation facilities' employees lagged behind the target number by almost 2000 (5 400 employees instead of the planned 7300 ). The number of Russian citizens who stayed at Kuzbass accommodation facilities in 2015 (314 800) was close to the target of 318500 people. In 2016, this figure increased significantly (429 000), tending to target indicator for 2020-2025. Mandatory certification of hotels with the assignment of stars will start only in 2018 and will be performed in several phases, and only by 2020 it will become clear how many Kemerovo region hotels correspond to the 3or more- star level.

In 2009-2017, Kuzbass did a lot for the development of tourism. Let us limit ourselves to a few examples which are mostly infrastructure projects implemented through publicprivate partnership are oriented at the longer (5-10 years) payback period [14]. Since 2011, a favourable economic zone 
in the territory of Tashtagol municipal district was created [15]. This decision determined the intensification of attracting private investors to the region. The main strategic directions were construction of roads, improvement of hotel complex territories, arrangement of parking zones, footpaths, and snowmobile and ATV routes. All these activities are aimed at ensuring the full year-round operation of Sheregesh tourist complex. The project of Sheregesh tourism and recreation cluster in Kemerovo region, created within the framework of the Federal target program "Development of domestic and inbound tourism in the Russian Federation (2011-2018)" [16], received funding from the federal budget. In 2014 - 2016, 3652.4 million rubles was attracted from non-budget sources, and 1565.4 million rubles was received from the budget [17: 185]. The funds were aimed for the creation of the 36 objects of tourist infrastructure. The building of Kuzedeevo Mundybash - Tashtagol highway was totally funded from budget sources. The hotel complexes ("Alpika", "Alpen Club", "Sport-hotel", "Taiga", "Tashtagolskiy Ostrog", and others), guest houses, catering facilities, entertainment and health complexes ("Sport-bar", "Yeti-Park", the thermal center "Silver springs", the health resort "Antler Baths"), etc. were built exclusively at the expense of private investors. The investors involved in the building of Sheregesh tourist complex are both local entrepreneurs and entrepreneurs registered in other Russian regions (Tomsk, Moscow, Nizhny Novgorod, etc.). For further promotion and development of the ski resort, a master plan was developed with the participation of the world-famous company "EcoSign". It is aimed at a systematic solution of a number of complexities with infrastructure. In particular, the project aims to define clearly the location of hotels, parking lots, walking areas, food facilities, new ski slopes and lifts.

Another example of private investment in the development of tourist infrastructure of Kemerovo region is the Tanay ski complex, located in Promyshlennovsky district not far from Lake Tanay. The first phase of the complex construction was finished in 2007, with more than 900 million rubles invested in the creation of the complex by "Sibirskiy Delovoy Soyuz" ("SDS") joint-stock company [18]. A hotel for 190 beds was built in the territory of the Tanay complex, and another hotel for 59 beds was built in the neighboring village of Vaganovo. The territory of the Tanay ski complex was completed with a snowboard park, a ski lift, two ski slopes, snow tubing and other objects. Also, a modern block-modular gas boiler and the second stage of the artificial snow formation system were put into operation. In 2017, 9 tracks for different categories of skiers' expertise were launched (the length of the longest track is $1350 \mathrm{~m}$ ). The complex was equipped with one chair lift and five ski lifts, as well as a belt conveyor, a track for tubing and a snowpark with big-air and jumps. Also, the complex has a skating rink, a playground, a mountain spring with a basin. The sanatorium "Tanay" provides health services for the prevention and treatment of a wide range of diseases. The ski complex "Tanay" also hosts a wildlife park. In 2009, "SDS" joint-stock company launched the Kuzbass parachuting centre "Tanay". The total cost of the construction of the Tanay complex amounted over 1.5 billion rubles [19].
The other skiing complexes built in the region are Gornaya Salanga, Gora Zolotaya, and Mount Yugus in Mezhdurechensk. The first stage of the construction of Gornaya Salanga resort was launched in 2006-2008. "Gornaya Salanga" joint-stock company invested more than 100 million rubles in the development of the territory. [20] Further development of the resort required the involvement of funding from the Monocities' Development Fund (140 million rubles) to provide infrastructure (roads, sewage system, water treatment facilities, energy supply, etc.), and the amount of 250-300 million rubles of further funding from the owner [21]. To date, 4 tracks whore length ranges from 930 to $1350 \mathrm{~m}$ with a height difference of $190 \mathrm{~m}$ have been opened, and 13 cozy chalets in the traditional Alpine style have been built. The resort offers a variety of sports, recreational and sightseeing services (ice rink and snowmobiling in winter; hiking, horseback riding, picnics and fishing in the forest lake, rafting, etc. in summer).

In addition to skiing and sports tourism, the "2025 Strategy for tourism development in Kuzbass" determines cultural and historical tourism among the leading attractions in the region. Kuzbass tourism industry has received a significant amount of investment from the regional budget for developing this sphere. A vivid example of the development of this type of tourism resources is Tomskaya Pisanitsa Museum-Reserve.

The Museum was established on the bank of the Tom' River in the location of the rock with petroglyphs that had been discovered in the beginning of the $17^{\text {th }}$ century. The Museum has been operating since 1988. The key tasks of the Museum are preservation, study and public presentation of the monument of rock art of federal importance "Tomskaya Pisanitsa", the architectural and ethnographic monuments in the open air, and the museum collections. The other key tasks include the preservation and study of the flora and fauna of the reserve and its historical landscape, as well as organization of educational and scientific tourism. The Museum gained the greatest popularity in the early 2000s, attracting tourists not only with scientific and with educational excursions and the opportunity to get acquainted with the historical heritage of the past, but also with rapidly developing entertainment attractions. The latter include folk festivals and interactive excursions; the Museum also provides the opportunity to organize an active and educational family vacation with a visit to the zoo, where animals of Siberia are collected. The Museum offers such entertainments as dog sledding, horses riding, quad-bikes riding, visiting a rope park and other attractions, participation in a river excursion, etc.

The Museum-Reserve receives funding from the regional budget. Its activities are also funded with the money earned as the result of providing tourist services. Tomskaya Pisanitsa also received support from private funds. The total amount of subsidies from the budget in 2017 amounted to 33512.99 thousand rubles. The Museum earned 28025.6 thousand rubles as the results of its business activities. Kemerovo region's entrepreneurs provide sponsorship to Tomskaya Pisanitsa in the form of charitable assistance and products for feeding the animals in the zoo and maintaining property of the Museum. The total amount of donations from private funds in 2017 amounted 421.04 thousand rubles [22: 34-35]. 
Another visible result of the implementation of the "2025 Strategy for tourism development in Kuzbass" was the creation of two tourism and recreation clusters [6], which demands further detailed consideration.

\section{CONCLUSION}

Today, the tourism industry is of strategic importance for the economy of Kemerovo region. The territory of Kemerovo region has great potential for the development of tourism development as one of the profitable sectors of the region's economy. Analysis of the region's tourism infrastructure shows the positive dynamics and quantitative growth of tourism facilities and the number of employees in this sector, as well as of its profitability. The increased attention of private investors to this sector is noted, which obviously proves its profitability and prospects. Regional authorities contribute to the effective development of tourism economic activities through setting legal norms as tourism occupies an important place in the context of the prospects of the region's economic development: attracting investments, increasing jobs, incomes, taxes, and other micro- and macroeconomic indicators.

\section{References}

[1] H. Halkier, D. K. Müller, C. Anastasiadou, L. Kiriyanova, N. Goncharova, F. Kagan et al. Tourist destination dynamics in Russia. Tourism development and public-private partnership in four nonmetropolitan destinations. Aalborg: Department of Culture and Global Studies, Aalborg University, 2016.

[2] E. V. Tolstykh and A. I. Litvak. "Evaluation of the influence of tourism on the socio-economic development of Kemerovo Region", in Actual problems of the Humanities and the Sciences, no. 5, pp. 68-73, 2011.

[3] A. Ovcharov. "Methodological problems of statistical study of regional tourism and tourist expenditure", in Economy of Region, no. 1, pp. 281287, 2015. DOI: $10.17059 / 2015-1-25$

[4] E. Kropinova. "Evaluation of Tourism Development Situation in the Russian Federation in 2000-2015: The Case of Kaliningrad Region”, in Mediterranean Journal of Social Sciences, 2015. DOI: 10.5901/mjss.2015.v6n6s7p165

[5] N. N. Yashalova, M. A. Akimova, D. A. Ruban, S. V. Boiko, A. V. Usova and E. R. Mustafaeva. "Prospects for regional developmen of industrial tourism in view of the analysis of the main economic indicators of Russian tourism industry", in Economic and social changes: facts, trends, forecast, no. 10, vol. 2, pp. 195-213, 2017. DOI: 10.15838/esc/2017.2.50.11.

[6] A. A. Zelenin and A. A. Pyatovskiy. "History of Statutory Regulation of Domestic Tourism in Russia in the 1990s - mid 2010s: Federal and Regional Aspects", in Bulletin of Kemerovo State University, no. 1, pp. 11-17, 2018. DOI:10.21603/2078-8975-2018-1-11-17.

[7] O. A. Denisova, A. P. Dubtsova, L. G. Kiriyanova, A. A. Surtseva A. A. Pyatovskiy, and K. V. Yumatov. "The interaction of the tourism industry stakeholders in the regions of the Siberian Federal District (by the example of Kemerovo region)", in Economics: Yesterday, Today and Tomorrow, no. 6 (12A), pp. 291-312, 2016.

[8] The Amount of Tourism Services provided. Summarized statistical data for 6 years (2009-2016) concerning the subject of the Russian
Federation. Retrieved from RussiaTourism Official Website, 2016. URL: https://www.russiatourism.ru/contents/statistika/statisticheskiedannye-po-rf/statisticheskie-dannye-po-subektam-rf-za-2015-god/

[9] E. I. Skripak and A. A. Surtseva. "Tourism development in Russia and in Kuzbass: Aware of the problems", in Bulletin of Kemerovo State University, no.2 (62), vol. 7, pp. 251-25, 2015

[10] Sheregesh, Kemerovo region, will become an all-year-round resort. Retrieved from RussiaTourism Official Website, 2016. URL: https://www.russiatourism.ru/news/11366/

[11] Strategy for social and economic development through 2025. Retrieved from the website of Kemerovo Region Administration, 2013. URL: https://ako.ru/upload/medialibrary/50f/Strategija_socialano_jekonomich eskogo_razvitija_Kemerovskoj_oblasti_do_2025\%20goda(1).docx

[12] Legal Acts Regulating the Sphere of tourism. Retrieved from the website of Kemerovo Region Department of Youth Policy and Sport, 2018 URL: http://www.dmps-kuzbass.ru/tourism/legislation/

[13] 2025 Strategy for tourism development in Kuzbass. Adopted by the Decree of Kemerovo Region Administration Board № 194-p dated 1.03.2013. Retrieved from the website of Kemerovo Region Administration, 2013. URL: https://ako.ru/upload/medialibrary/14e/ Strategija_razvitija_turizma_v_Kemerovskoj_oblasti_do_2025_goda_ot 01.03.2013 goda №194-r(6).doc

[14] Kemerovo Region Administration Decree on creation of a favourable economic zone in the territory of Tashtagol municipal district. Adopted by the Decree of Kemerovo Region Administration Board № 1028-p dated 02.12.2010. Retrieved from the Electronoc Fund of Documents on Legal and Technical Norms. URL: http://docs.cntd.ru/document/ 990311160

[15] N. A. Zaitseva, E. G. Kropinova, V. S. Korneevets, I. I. Dragileva, and A. D. Chudnovskiy. "The long-term forecast of the Russian tourism development", in International review of management and marketing, no. 6, vol. 5, pp. 103-110, 2016

[16] Decree No. 1407 dated 18.12.2014 within the State program "Development of culture and tourism" for 2013-2020 in the Federa Target Program "Development of domestic and inbound tourism in the Russian Federation $(2011$ - 2018)". Retrieved from the website of the informational and legal portal "Garant.ru". URL: http://base.garant.ru/ 70830634/\#friends

[17] Atlas of investment projects in the sphere of tourism implemented in the subjects of the Russian Federation, 2017. Retrieved from RussiaTourism Official Website. URL: https://www.russiatourism.ru/urgent/13886/

[18] A. I. Litvak and E. V. Tolstykh. "Role of the investment potential in the social and economic development of Kemerovo Region", in Bulletin of Kemerovo State University, no.3, pp. 292-296, 2012

[19] V. G. Boreisha. "Diversification of economy as a factor of sustainable development of the regional rural territories (Russia, Kemerovo)", in Problems of Modern Economics, no 4 (56), pp. 215-218, 2015

[20] Gornaya Salanga invested more than 100 million rubles over two years in a trourist complex in Kuzbass. Retreived from the website of the tourism portal VOtpusk.ru, 9 April 2008 URL: https://www.votpusk.ru/ news.asp?msg=192242

[21] New tasks for Kuzbass tourism industry. Retreived from the website of the Tourism and Recreation Cluster of Kemerovo, 10 November 2017 URL: http://visit-kuzbass.ru/ru/sobytiya/novosti/4758-novye-zadachidlya-kuzbasskogo-turizma.html

22] Public report of the activities of State autonomous cultural institution of Kemerovo Region "Historical, cultural and natural Tomaskaya Pisanitsa Museum-Reserve" in 2017. Retrieved from the official website of natural Tomaskaya Pisanitsa Museum-Reserve. URL: http://www.gukmztp.ru/doc/Otchet2017.pdf 